Journal of Advanced Research in Fluid Mechanics and Thermal Sciences

\title{
A Novel Renewable Energy Approach for Cairo International Airport "CIA" based on Building Information Modeling "BIM" with Cost Analysis
}

\author{
Mohamed S. Emeara ${ }^{1}$, Ahmed Farouk AbdelGawad ${ }^{1}$, Ahmed H. El Abagy ${ }^{1,}{ }^{*}$ \\ Mechanical Power Engineering Dept., Faculty of Engineering, Zagazig University, Zagazig 44519, Egypt
}

\section{ARTICLE INFO}

\section{Article history:}

Received 6 May 2021

Received in revised form 10 July 2021

Accepted 15 July 2021

Available online 6 August 2021

\section{Keywords:}

Cairo International Airport; Solar energy;

BIM; PV; Wind Rose; PVsyst; Autodesk Revit; Autodesk Green Building Studio

\section{ABSTRACT}

Renewable energy has become an increasingly cost-effective commerce preference for airports on account of technological advancement, market ripeness and public-sector investment. Airports have merits that promote the financial viability of on-site renewable energy, in particular for solar photovoltaics $(P V)$. Solar energy systems can produce electricity in the day time when sun ray is available and it is cost efficacious. Solar system can be installed either fixed or adjustable to increase the amount of solar energy received via preservation the incident solar beam radiation normal to the system surface as possible. $B I M$ has the ability to achieve a more energy-efficient building to improve the sustainability through energy analysis, solar analysis and wind analysis. PVsyst software was used to model the power generation and to design the whole $P V$ system properly. Autodesk Revit and Autodesk Green Building Studio, during simulation, can give the annual wind Rose. This paper aims to apply analysis for $P V$ system energy generation and its components to give initial cost, and annual cost as well as providing cost payback period which is an important indicator to define the amount of time it takes to recover the cost of an investment. Three cases of $P V$ areas were considered, namely: building roofs, parking area, and $P V$ land plant, in Cairo International Airport, by using the proposed selected $P V$ cleaning methods. The system components were analyzed by PVsyst software. Wind Rose was obtained by Autodesk Revit and Green Building Studio. The results revealed that an annual energy generation of around $70 \mathrm{GWh} / \mathrm{yr}$ is expected, the initial cost is about $463 \mathrm{MEGP}$ and the cost payback period is less than $6 \frac{1}{2}$ years.

\section{Introduction}

Airports are described as energy intense consumer. The electrical need of an airport can be classified as airside energy request (consisting of the airfield lighting, radio navigation systems, and any auxiliary buildings) and landside energy request (terminal buildings and other buildings). Usually, international airports are used by millions of people during the year [1]. Airports require energy for transporting people and goods efficiently. Airports purchase electricity from the national grid, which is a large network of electricity transmission lines [2]. Renewable energies, e.g., PV systems are used on the whole to produce electric power to meet the growing demand for electricity [3]. Wind and

\footnotetext{
* Corresponding author.

E-mail address: ahmed.elabagy@gmail.com
}

https://doi.org/10.37934/arfmts.85.2.80106 
solar electricity generation are prominently in energy systems that meet these renewable, lowcarbon energy goals [4]. The solar energy as a renewable source has been applied which have potential for future energy applications [5] and become one of the most essential alternative safe sources for disbanding these problems [6]. Photovoltaic solar system is a technology that enables conversion of solar energy into electricity [7]. Photovoltaic $(P V)$ is a manner of generating electrical power by converting solar radiation into direct current electricity using semiconductors that exhibit the photovoltaic effect [8]. Where solar radiation is converted into electrical energies [9]. Photovoltaic power generation utilizes solar panels that consist of a number of cells containing a photovoltaic material [10].

It is worth to mention that solar PV plants are being built-up in many airports around the world [11]. PV modules can be built-up on roof top, over car parking area, utilized land area, and can also be integrated with buildings [1].

The orientation of the solar system with respect to the sun's position is the fundamental factor affecting the generated energy and, hence, the overall system performance. Orientation is very serious factor for designing and installing the solar systems, which is fundamentally a function of the system tilt angle and facing [6]. There is PV system with seasonal changed angles. Solar elevation angle moves periodically over the year, and thus seasonal electricity generation can be promoted with different tilt angles [6].

\subsection{Building Information Modeling (BIM)}

$B I M$ is a modelling technology and connected collection of processes to create, communicate, and resolve building models [12]. There is a rapid increase of firms using Green BIM to perform energy performance simulations [12].

\subsubsection{PVsyst software}

The PVsyst software is used to model the power generation [13]. PVsyst is one of the best simulation software to evaluate the performance of a solar PV power plant [14]. PVsyst software is used to design the whole PV system properly [3]. PVsyst is able to estimate the performance of grid connected, stand-alone and $D C$ solar systems based on the defined module and selected location [14]. PVsyst is a PV system design and simulation tool, which provides pre-sizing of inverter and $P V$ panels. PVsyst software has a great set of meteorological data for all over the world, and also allows manual insertion of data if not available in the database. To get the sizing and appropriate design with technical and economic evaluation of the PV system, we need to provide all the inputs necessitated by the software, e.g., (1) Location, (2) Tilting angle, (3) Azimuth angle, (4) PV module and inverter specification [3]. On a case study of Cairo International Airport, PVsyst simulation was found to have an accurate simulation and its results are very close to the average of the three study methods used PVsyst, Autodesk Revit and theoretical calculations [14]. The PVsyst simulation provides report for the output values of produced energy, performance ratio $(P R)$, graphs and simulation tables of results over the year [14]. On a case study of Cochin International Airport, PVsyst software was found to match closely with actual site data [1].

\subsubsection{Autodesk Revit software}

Revit enables model check, energy simulation and other analyses [14]. Revit is a $4 D B I M$ tool that is able to plan, using the building material data already available, or by integrating new material along 
with its properties. Building Energy model can be developed and submits automated Life Cycle Assessment based on energy, cost and greenhouse gas emissions [15].

\subsubsection{Autodesk Green Building Studio (GBS)}

Revit Plug-in and Autodesk Green Building Studio are used to prophesy energy savings, also can be used for calculating the cooling or thermal load. The radiation data and the annual wind rose (speed distribution) can be obtained using Revit and Green Building Studio softwares from Autodesk [13]. To perform the energy simulation, the model was exported from Revit using gbXML, then using Green Building Studio to read the file [16].

\section{Research Methodology}

\subsection{Structure of PV Grid-Connected System}

The PV Grid-Connected System consists of [17]

i. PV modules.

ii. Balance of System "BOS" which covers

- An inverter

- Switching and protection elements

iii. Mounting System for the PV modules.

\subsubsection{PV module}

The PV module converts the solar radiation into electricity [7]. The module efficiency is a measure of the percentage of solar energy converted into electricity [18].

\subsubsection{Balance of system}

i. Inverter: Inverters convert $D C$ electricity into $A C$ from the $P V$ array and can connect smoothly to the electricity grid [18].

ii. Switching and protection elements: Electrical connections, including wiring, disconnect switches, fuses, and breakers are required for both safety and equipment protection [18]. The cables of the $P V$ modules connected in series are combined into parallel strings in a $P V$ junction box containing over-voltage protection and possibly string diodes. From there, the $D C$ main cable leads to the inverter. It is better to install $D C$ circuit-breaker before the inverter enables disconnection of the system for maintenance work at the inverter [19].

\subsubsection{Mounting systems}

The mounting system can be either directly anchored into the ground or ballasted on the surface without ground permeation. Mounting systems should be designed to resist local wind loads, which range from 145-195 km/h for most areas or $210 \mathrm{~km} / \mathrm{h}$ or more for areas with hurricane potential [18].

i. Fixed mounting tilt angle: The mounting of the panel is fixed at a specified tilt angle through the year as shown in Figure 1 [20].

ii. Adjustable mounting tilt angle: The panel mounting can be adjusted for two tilt angles of summer and winter. 
iii. Carport mounting: This mounting is used in car parking for holding the $P V$ panels as shown in Figure $2[20]$.

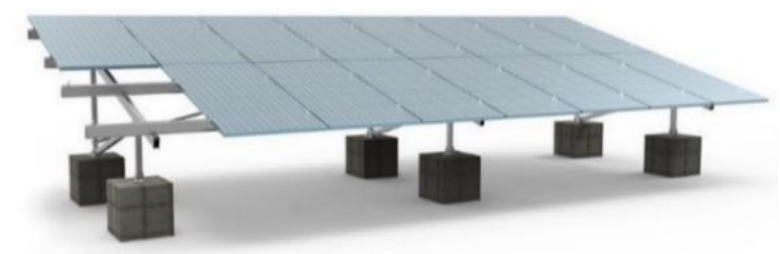

Fig. 1. Fixed-mounting tilt-angle stand [20]

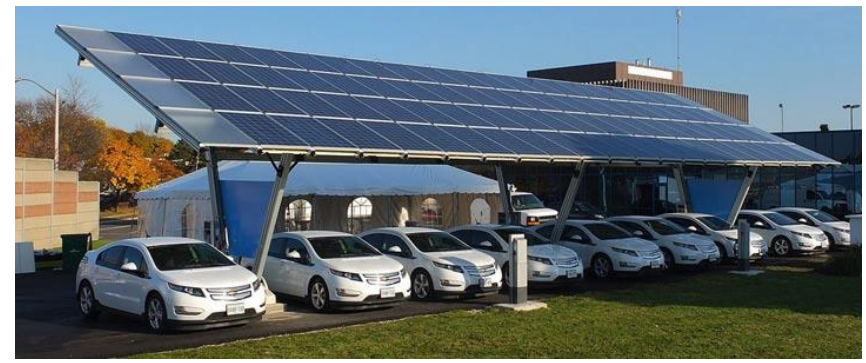

Fig. 2. Carport-mounting stand [20]

\subsection{Dual-Seasonal Tilt Angles}

The tilt angle is the vertical angle of the panels [11]. As the performance of the solar system relied on the amount of solar energy reached to its surface, the dual tilt angles affect the generated energy and the system performance [6].

\subsection{Lifetime of the PV System}

$P V$ modules, the key component of $P V$ systems, are ensured for a duration in the range 25-30 years by most suppliers, which suggests that the life of the $P V$ modules is $25-30$ years $[17,18]$.

\subsection{Lighting System}

Lighting should be installed on the $P V$ panel area for maintenance or repair works needed during operation.

\subsection{Drainage System}

Drainage system is much recommended due to the cleaning workers needed. It simplifies draining water of cleaning, and so reducing cleaning manpower, strainers and suction diffusers to be installed on the system in order to protect the system.

\subsection{Wind Rose}

It is important to define the wind rose of the project in order to help on selecting the suitable mounting. 


\subsection{Cleaning of PV Panels}

Soiling and dust lead to power loss of the $P V$ panels based on physical and chemical properties of dust particles [21]. The maintenance of solar panels is challenging due to soiling [22]. There are different cleaning methods that are listed in the following sub-sections.

\subsubsection{Cleaning methods overview: mechanical removal of dusts}

The mechanical methods of dust removal are divided into brushing, blowing, vibrating, and ultrasonic driving [10].

i. The brushing methods: They clean the solar cell with broom or brush that is driven by the machine. However, firstly, due to the small size and the strong adhesion of the dusts, the cleaning method is ineffectual. Secondly, the abominable working environment of the solar cell makes it difficult for the maintenance of the machine. Finally, the solar cell surfaces may be damaged by the brush when wiping [10].

ii. The blowing method: The solar cell can be cleaned with wind power, which has a low efficiency with the unsatisfactory maintainability of the blower [10].

iii. Vibrating and ultrasonic: It is also an adequate mechanical cleaning method. The key of this strategy consists of the driving method, the frequency and the amplitude of the solar cell [10].

\subsubsection{Forced flow from air conditioning systems}

Air flow from the air-conditioners fans is used to force the flow on solar panels for dust removal. They could be implemented in various countries with wide availability of air conditioners [22].

\subsubsection{Self-cleaning and tracking PV panels}

It is based on using $1000 \mathrm{rpm}$ and $10 \mathrm{rpm} \mathrm{DC}$ motors for cleaning and tracking, with connected threaded-rod to the $D C$ motor. A wiper is connected to the threaded rod. Then, the rotation of the motor rotates the wiper. Also, the system has a microcontroller to help for automatic tracking and cleaning as illustrated in Figure 3 [21].

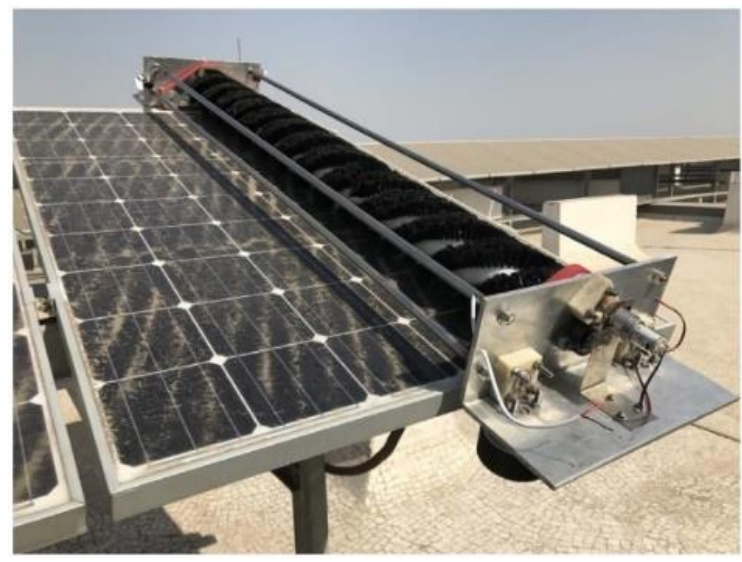

Fig. 3. Self -cleaning and tracking $P V$ panels [21] 


\subsubsection{Rainfall cleaning}

The rainwater incident on the tilted $P V$ panels is used to clean the dust of panel surface. Ordinarily, this procedure leaves behind the dust which is stuck onto the panels due to moisture, and in general needs heavier rainfall to remove it [22].

\subsubsection{Pressurized water-based cleaning}

This method needs large amounts of water and under continuous high pressure to repulse any soiling particulate matter stuck on the $P V$ panel surface. There are many disadvantages of this method such as loss of water in massive quantities, chances of chemical sedimentation on $P V$ panel edges, reduced efficiency as the pressurized water system expends considerable amount of power, risks of water blocking, and refilling of water tanks [22].

\subsubsection{Manual cleaning}

Dust particles are scoured using special brushes. Brushes connected with a direct water supply enable simultaneous scrubbing and washing. It is extremely more efficient than rainfall cleaning in reinstating the solar panel surface to cleaner condition. It requires skilled labor to clean off the soiling [22].

\subsubsection{Electrodynamic Screens (EDS)}

An electrodynamic screen (EDS) placed on a solar panel can assure automated removal of deposited dry dust. Using high voltage supplies to power electrodes of a clear screen which assists removing the charged and uncharged dust particulate matters by shifting them over an edge of the panel surface [22]. There is a risk of screen degradation due to UV rays. Also, the system needs highvoltage supply to produce the electric field, therefore decreasing the generation efficiency by $15 \%$. It also proves to be not effective for wet or cemented dust particulates, and so it is less efficient for small-size particles [22].

\subsubsection{Robotic PV cleaner}

The robot has brushes, in accordance with the size of the solar panels [22]. The robot can be used for cleaning by remote control. The robot has a battery that can be charged every 2 or 3 hours. There is a supporting hose in order to feed the robot with water. No need for pressurized water, and so no need for water tank and the other devices of that system. The robot can work with the pressure of the exist water system of the building. Accordingly, little manpower needed, also there is no large amount of water consumption. Figure 4 shows a Robotic PV Cleaner [23]. 


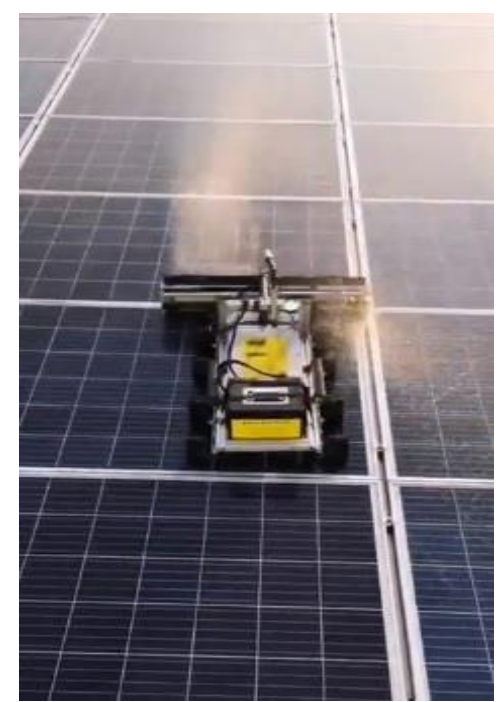

Fig. 4. Robotic $P V$ cleaner [23]

\subsubsection{Truck PV cleaner}

A truck cleaner is used in $P V$ land areas. This method covers large $P V$ cleaning area daily. Truck cleaner can be used mostly on $P V$ land plants on Airports and Oil fields in the desert, where there are large areas of $P V$ plants and can provide good distances between $P V$ rows. Figure 5 shows a truck $P V$ cleaner.

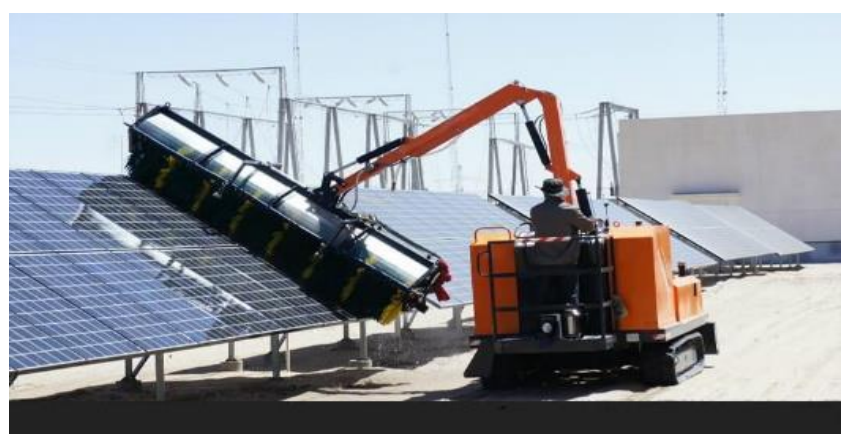

Fig. 5. Truck $P V$ cleaner [24]

\subsubsection{Nanotechnology}

This method is based on using Nano-film of titanium oxide, chemical coating, and Nano-patterned fabrication of glass surface. The coating does not permit dust to stick to surface. More dust accumulates when the coating deteriorates due to $U V$ rays. The water rolls off on the tilted surface like "a sphere rolling down a slide". The water evaporates, leaving remnants that need removal. It is moderately efficient in rains and regular washing is required [22].

\subsubsection{Water sprinkler cleaning system}

The method is based on a constant pressurized water in a pipework, and sprayed out of sets of water nozzles. Each PV module is cleaned by a set of three nozzles, which can be switched "on" and "off" by a programmable logic controller $(P L C)$ unit through an electric solenoid valve [25]. Figure 6 shows a simple system [25]. 


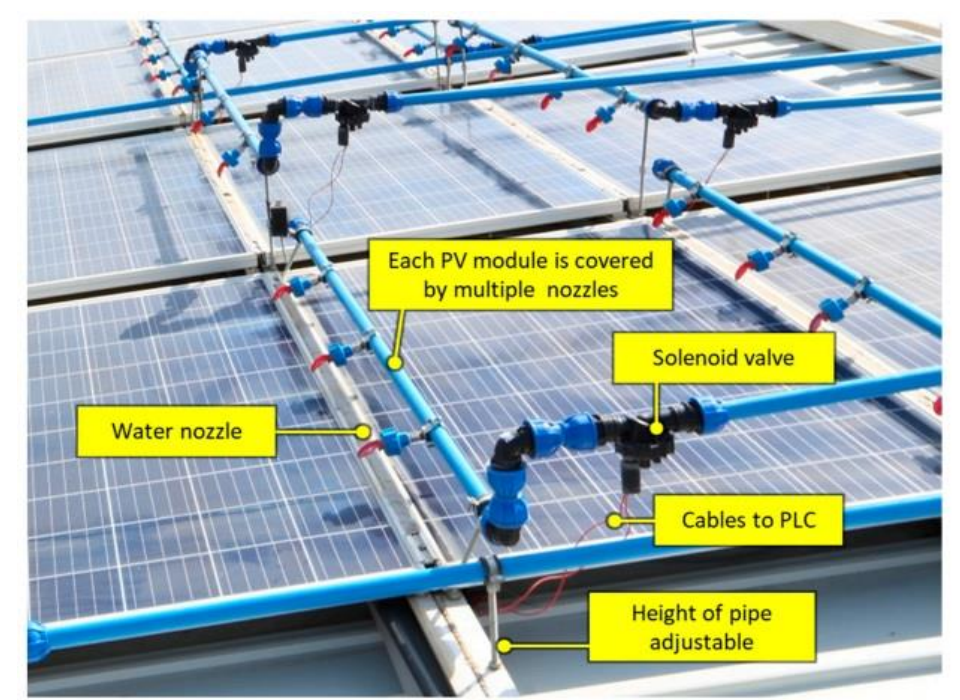

Fig. 6. Water sprinkler cleaning system [25]

\subsection{Cost of PV Grid-Connected System}

The cost of a $P V$ system relies on the system size and other factors like geographic location, mounting system, $P V$ module type, amongst others [18].

\subsubsection{Initial investment}

The initial investment is covering the following

i. Cost of $P V$ systems,

ii. Cost of $B O S$, which includes inverters, switching, and protection elements, as well as assembly cost.

iii. Cost of mounting system.

iv. Cost of any other auxiliary system such as lighting, and drainage systems.

\subsubsection{Annual costs}

The annual costs represent the annual operation and maintenance "O\&M" costs, and the annual insurance [17].

i. Operation and maintenance costs: The operation and maintenance $(O \& M)$ costs represent the financial payment during operation period, including service, spare parts, insurance, management and other expenses [26]. Operation and maintenance costs are through the whole lifetime of solar PV system, such as regular cleaning, monitoring of performance and replacement needed [17].

ii. Insurance costs: Annual insurance rate for $P V$ system [17].

\subsubsection{Cost payback period}

The payback period refers to the amount of time it takes to recover the cost of an investment [27]. 


\subsection{Calculation Methods}

i. In this study, $P V$ system analysis was applied in order to obtain the $P V$ system generation, and the $P V$ system components by using PVsyst for three cases as follows

- CIA Building Roofs

- CIA Parking Area

- CIA PV Land Plant

ii. Use fixed tilt angles for the building roofs (horizontal plane, azimuth angle $0^{\circ}$ and tilt angle $0^{\circ}$ ) in order to utilize available area without placing a large spacing between rows of $P V$ modules to avoid shading losses, thus obtaining a larger $P V$ area and higher generation energy, with an adjustable stand in order to have better spacing on maintenance.

iii. Use fixed tilt angles for the parking area (horizontal plane, azimuth angle $0^{\circ}$ and tilt angle $0^{\circ}$ ) in order to utilize available area without placing a large spacing between rows of $P V$ modules to avoid shading losses, thus obtaining a larger $P V$ area and higher generation energy, with a car port stand.

iv. Use seasonal dual tilt angles for the $P V$ Land Plant (azimuth angle $0^{\circ}$, and seasonal tilt angles are $10^{\circ}$ in summer and $50^{\circ}$ in winter) due to having large area, so we have good space between rows of $P V$ modules without shading losses and thus get higher generation energy, with an adjustable stand.

v. Getting the wind rose by using Revit and Green Building Studio in order to select the suitable mounting stand.

vi. Performing cost calculation and getting the cost results of the initial cost for the three study cases.

vii. Obtaining the results of the annual cost by using the following selected four cleaning methods

- Manual Cleaning

- Water Sprinkler System

- Robotic / Truck PV Cleaner

- Nanotechnology

viii. Finally, getting the Cost Payback Period.

ix. As some cost values are not available on the public domain, the Authors had to estimate these values based on the available data of similar cases, and the Authors' personal communication and their experience.

\subsubsection{PV system generation energy}

PVsyst was used for energy analysis and getting the energy generation by using PV panel 540W, $21.2 \%$ module efficiency.

\subsubsection{PV system annual income}

After getting the annual energy generation results, the annual income can be calculated in EGP as per this formula [28]

$\left(30 \% \times 8.40\right.$ Dollar $\frac{\text { Cent }}{k W h} \times$ Equivalent price of dollar on the time to issue the tariff $)+(70 \% \times$

8.40 Dollar $\frac{\text { Cent }}{k W h} \times$ Equivalent price of dollar on the maturity time) 
Considering the maturity time is January 2021 , the formula will be as follows

$\left(30 \% \times 8.40\right.$ Dollar $\left.\frac{\text { Cent }}{k W h} \times 8.88\right)+\left(70 \% \times 8.40\right.$ Dollar $\left.\frac{\text { Cent }}{k W h} \times 15.70\right)$

\subsubsection{PV system components}

PVsyst was used for energy analysis and getting the $P V$ system components.

\subsubsection{Wind rose}

The building model was exported from Revit using $g b X M L$, and then Green Building Studio, during energy simulation, can obtain the wind rose of the project.

\subsubsection{Initial cost}

i. $\quad P V$ system lifetime: The lifetime of the $P V$ system was considered as $25-30$ years $[17,18,29]$.

ii. $P V$ panel cost: It is based on the availability in the local and international electronic markets. The local markets such as Solar Market Egypt, which is an Egyptian solar Market for solar products and services in Egypt, and Global Techniques for Energy, which is an Egyptian solar products supplier. Also, one can refer to international markets such as ENF Solar, which is for Solar Companies and Products, and PV Solar First [20,29-31]. After reviewing, the average cost of $P V$ panel $540 W$ is 3,400 EGP.

iii. BOS Cost

- Inverter cost: As per ENF Solar and Solar Market Egypt, the average cost is 2,200 EGP/1kWac [29].

- Switching and protection elements cost: Referring to Eicker [19], the considered cost is $5 \%$ of $P V$ panels cost [19].

- Assembly cost: This includes assembly for the electrical wiring, the PV panels, inverters, and switching and protection elements. As per Solar Technologies for Building Guide by Eicker [19], the considered cost is $20 \%$ of PV panel cost.

iv. Lighting system cost: The estimated cost is $10 \%$ of $P V$ panels cost.

v. Mounting system cost

vi. The mounting stand should be selected to resist the wind load of the project. Firstly, one gets the wind rose by using Autodesk Revit and Green Building Studio. Then, one selects the mounting stand, as per Solar suppliers $[20,29,30]$. There are various stands that can resist the high wind loads such as $144 \mathrm{~km} / \mathrm{h}, 150 \mathrm{~km} / \mathrm{h}$, and $216 \mathrm{~km} / \mathrm{h}$. Also, one can get the average cost of the mounting stand.

- Adjustable-mounting tilt angle cost: One stand for 20 panels costs 10,000 EGP. For installation cost, it is estimated that a team of 2 skilled technicians can install 3 stands for 60 panels per day. Salary of 2 technicians is 500 EGP/day.

- Carport-mounting cost: One stand for 20 panels costs 20,000 EGP. For installation cost, it is estimated that a team of 4 skilled technicians can install 3 stands for 60 panels per day. Salary of 4 technicians is 1,000 EGP/day.

vii. Drainage system cost: The drainage system consists of drainage pipes (can use UPVC pipe), pipe fittings, and materials accessories. First, one calculates the estimated length of pipes needed for the $P V$ panel area in order to get the cost of total pipes required. The UPVC pipe 
(4m) cost is EGP 80 as per Misr El Hegaz [32]. Adding fittings estimated cost is $25 \%$ of the pipes cost, plus the accessories estimated cost is $5 \%$ of the pipes cost. For installation cost, it is estimated as a team of 2 skilled technicians can install 200 meters per day. Salary of 2 technicians is $500 E G P /$ day.

\subsubsection{Annual cost for initial installed systems}

The initial installation systems are $P V$ panels, BOS, mounting system, and lighting and drainage systems.

i. Maintenance cost for $P V$ panels, $B O S$, lighting and electronic devices

- Maintenance for PV panels, BOS, lighting and electronic devices was estimated as: Team of 2 skilled technicians perform the schedule maintenance for $600 \mathrm{PV}$ panels per day. Salary of 2 technicians is $500 \mathrm{EGP} /$ day, then one can get the yearly cost.

- Annual cost of inverters replacements: The lifetime of the inverters is 10 years, accordingly, the replacement will be twice during 25 years. So, we can obtain the annual replacement cost in equivalent of the replacement cost through 25 years.

- Annual insurance: Referring to Hernández-Moro and Martinez-Duart [17], the considered annual insurance cost is $0.15 \%$ of the $P V$ panels cost.

ii. Maintenance cost for drainage system

- The estimated maintenance manpower: Team of 2 skilled technicians can cover the monthly maintenance for $3,000 \mathrm{~m}^{2}$ of the $P V$ panel area. Salary of 2 technicians is 500 $E G P /$ day.

- The estimated required replacement drainage materials: Drainage pipes are $10 \%$ of the installed quantity, plus fittings are $20 \%$, plus accessories are $10 \%$. Accordingly, we can obtain the annual replacement cost in equivalent of the replacement cost through 25 years.

\subsubsection{Annual cost by using manual cleaning}

The cost includes annual cost of initial installed systems as mentioned in section 2.9.6 in addition to the following parameters

i. Cleaning manpower cost: Estimated as a team of 2 skilled labors can perform the manual cleaning for $110 P V$ panels per day. So, one can get the required number of teams. Salary of 2 labors is $500 E G P / d a y$, thus one can obtain the yearly cost.

ii. Cleaning special tools cost: After getting the required number of cleaning teams, we have to provide cleaning special tools for each team. According to local market, the cost and the tools lifetime can be as follows [29]: Special ladders: One ladder cost 1,200 EGP and its life time is 2 years. Cleaning package: One package cost 800 EGP and its life time is 1 year. Cleaning brushes: One brush cost 80 EGP and its life time is 1 month. Accordingly, we can obtain the annual replacement cost in equivalent of the replacement cost through 25 years.

iii. Cleaning water usage cost: Monthly need is $6 L / P V$ panel including losses that may occur. Then, the water usage cost is $4.55 \mathrm{EGP} / \mathrm{m}^{3}$ [34]. 


\subsubsection{Annual cost by using water sprinkler system}

The cost includes annual cost of initial installed systems as mentioned in section 2.9.6, in addition to the following parameters:

i. Water piping \& sprinklers installation, and maintenance cost

- Water piping installation: (using PPR Polypropylene pipe), pipe fittings and materials accessories. First, one calculates the estimated length of pipes needed for the $P V$ panel area in order get the cost of total pipes required. The cost of insulated $P P R$ pipe is $60 \mathrm{EGP} /$ meter [35]. Then, one adds fittings estimated cost as $25 \%$ of pipes cost, and accessories estimated cost as $5 \%$ of pipes cost. For installation cost, it is estimated that a team of 2 skilled technicians can install 200 meters per day. Salary of 2 technicians is $500 \mathrm{EGP} /$ day.

- Water sprinklers installation: Three sprinklers are needed for each panel and the cost is $30 \mathrm{EGP} / 3$ sprinklers [23]. For installation cost, it is estimated that a skillful technician can install 600 sprinklers per day. Salary of 1 technician is $250 \mathrm{EGP} /$ day.

- The estimated required replacement water pipes \& sprinklers materials: Water pipes are $10 \%$ of the installed pipes quantity, plus fittings are $20 \%$ of the installed quantity, accessories are $10 \%$, and sprinklers are $10 \%$. So, we can obtain the annual replacement cost in equivalent of the replacement cost through 25 years.

- The same drainage system maintenance team can perform maintenance on both the drainage and water systems.

Accordingly, we can obtain the annual cost equivalent to the installation and maintenance cost for 25-year lifetime.

ii. $P L C$ and electronic devices installation and maintenance cost

- $\quad P L C$ : The estimated required quantity for Building C is 7 PLCS (installation) 1 PLC (spare part). For Building $B$, it is 9 PLCs (installation) $+1 P L C$ (spare parts). For Parking, it is 10 PLCs (installation) +2 PLCS (spare parts). For 11 PBBs, they need 11 PLCS (installation) $+1 P L C$ (spare part). For PV Plant is 16 PLCs (installation) +2 PLCs (spare parts). The PLC average cost in the local market is 4,500 EGP/PLC [23,33].

- Electronic cables: First, one calculates the estimated length of cables needed for the $P V$ panel area in order get the cost of total cables required. The average cost is 10 $E G P /$ meter $[23,33]$. The spare parts needed are estimated as adding $10 \%$ of the total installed cables.

- Solenoid valves: Each panel needs 1 solenoid valve. The average cost is 200 EGP/one solenoid valve. The spare parts needed are estimated as adding $10 \%$ of the quantity.

- Estimated installation cost for PLC and electronic devices: Team of 2 skilled technicians can install the devices and their wirings for $500 \mathrm{~m}^{2}$ of the $P V$ panel area. Salary of 2 technicians is $500 \mathrm{EGP} /$ day.

- Spare parts for PLC and electronic devices are valid for the replacements needed for 25 -year lifetime. Accordingly, we can obtain the annual cost equivalent to the installation and maintenance cost for 25-year lifetime. 
iii. Cleaning manpower cost: It is estimated that a team of 2 skilled labors can perform the manual cleaning for $400 \mathrm{PV}$ panels per day. So, one can get the required number of teams to perform the cleaning for all panels monthly. Salary of 2 labors is $500 E G P / d a y$, accordingly, one can obtain the yearly cost.

iv. Cleaning special tools cost: After obtaining the required number of cleaning teams, we have to provide cleaning special tools for each team. As per mentioned in Section 2.9.7.

v. Cleaning water usage cost: Monthly need is $5 \mathrm{~L} / o n e \mathrm{PV}$ panel including losses. The one cubic meter of water costs 4.55 EGP [34].

\subsubsection{Annual cost by using robotic PV cleaner}

The cost includes annual cost of initial installed systems as mentioned in section 2.9.6 in addition to the following parameters:

i. Cost of required and maintenance for Robotic cleaner \& brushes

- Required robotic cleaners: Specifications of selected robotic cleaner applicable for $P V$ cleaning: cleaning capacity is $400 \mathrm{~m}^{2} / \mathrm{h}$, sleep rooftop include up to $60^{\circ}$. The working hours of the robotic battery is $2 \mathrm{~h} 30$. Remote control with remote range $200 \mathrm{~m}$ is used. The robotic cleaner lifetime is 5 years. It is able to use the water pressure of the building 2.5-5 bar. The water consumption is 0.2 to $0.8 \mathrm{~L} / \mathrm{m}^{2}$. The robotic cleaner can be used 3 different times daily. So, one can clean $P V$ panel area of 1,200 $\mathrm{m}^{2}$ per day. The robotic cleaner average cost is 250,000 EGP [23].

- Robotic brushes: Specifications of the robotic brushes: The brush lifetime is 100,000 $\mathrm{m}^{2}$ of cleaning work. The robotic cleaner brush average cost is 500 EGP [23].

- Annual visits for robotic schedule maintenance cost are estimated as 10,000 EGP/one team. Estimated needed is 3 teams for buildings roofs, parking area, and $P V$ land plant.

ii. Cleaning manpower cost: It is estimated that a team of 2 skilled labors can perform the manual cleaning for $500 \mathrm{PV}$ panels per day. So, one can get the required number of teams to perform the cleaning for all panels monthly. Salary of 2 labors is $500 E G P /$ day, accordingly, one can obtain the yearly cost.

iii. Cleaning special tools cost: After obtaining the required number of cleaning teams, we have to provide cleaning special tools for each team as mentioned in Section 2.9.7.

iv. Cleaning water usage cost: Monthly need is $3 L /$ one $P V$ panel including losses. The cubic meter of water costs 4.55 EGP [34].

\subsubsection{Annual cost by using truck PV cleaner}

The cost includes annual cost of initial installed systems as mentioned in section 2.9.6 in addition to the following parameters

i. Cost of required and maintenance for Truck cleaner \& brushes

- Required truck cleaners: The life time of the truck cleaner is 12-15 years. As truck cleaner covers large $P V$ cleaning area daily, so, one truck is needed to cover 125,000 $\mathrm{m}^{2}$ of the PV Plant, plus another one to cover the lifetime of 25 years. The average cost of truck cleaner is 2,500,000 EGP [23].

- Robotic brushes: The brush lifetime is $200,000 \mathrm{~m}^{2}$ of cleaning work. The brush average cost is 10,000 EGP [23]. 
ii. Annual visits for schedule maintenance cost are estimated as 50,000 EGP/one team. One team is needed for one $P V$ plant.

iii. Cleaning manpower cost: Estimated as a team of 2 skilled labors can perform the manual cleaning for $500 \mathrm{PV}$ panels per day, and so can get the required number teams to perform the cleaning for all panels monthly, pay for 2 labors is $500 \mathrm{EGP} /$ day, accordingly can obtain the yearly cost.

iv. Cleaning water usage cost: Need monthly for $10 L / 1 \mathrm{PV}$ panel including losses, the $\mathrm{m}^{3}$ of water costs 4.55 EGP [34].

\subsubsection{Annual cost by using nanotechnology}

The cost includes annual cost of initial installed systems as mentioned in section 2.9.6 in addition to the following parameters

i. Cost of required Nano coating materials and coating works.

- Nano coating materials cost: The Nano coating effect lasts for 4-5 years and to be used as $20-25 \mathrm{ml} / \mathrm{m}^{2}$. As the coating is valid up to 5 years, the coating is needed every 5 years through the 25 years. The Nano coating average cost is 3,000 EGP/1,000 $\mathrm{ml}$ [36].

- Coating works: Team of 2 skilled technicians can perform coating works for $800 \mathrm{~m}^{2}$ per day. Salary of 2 technicians is $500 E G P /$ day. This work will be needed every 5 years through the 25 years.

Accordingly, we can obtain the annual cost equivalent to the required cost for 25 -year lifetime.

ii. Cleaning manpower cost: It is estimated that a team of 2 skillful labors can perform the manual cleaning for $300 \mathrm{PV}$ panels per day. So, we can get the required number of teams to perform the cleaning for all panels monthly. Salary of 2 labors is $500 E G P / d a y$, accordingly, we can obtain the yearly cost.

iii. Cleaning special tools cost: After obtaining the required number of cleaning teams, we have to provide cleaning special tools for each team as mentioned in Section 2.9.7.

iv. Cleaning water usage cost: Monthly need is $3.5 \mathrm{~L}$ /one $P V$ panel including losses that may occur. The cubic meter of water costs 4.55 EGP [34].

\subsection{PV System Cost Payback Period}

The payback period calculation is determined by counting the number of years it takes to recover the funds invested. We can calculate the cost payback period as in Eq. (3) [27].

Cost payback period $=\frac{\text { Investment required }}{\text { Net annual cash flow }}$

Net annual cash flow $=$ Income per year - Annual cost per year

\section{Results}

\subsection{PV-System Generation-Energy Results}

Applying simulation was applied by PVsyst for three cases of $P V$ application: building roofs, parking area, and $P V$ land plant in Cairo International Airport. Table 1 illustrates the energy generation results using $P V$ panel $540 \mathrm{~W}, 21.2 \%$ module efficiency using horizontal plane, azimuth 
angle $0^{\circ}$ and tilt angle $0^{\circ}$ for building roofs and parking area, and using dual-seasonal tilt angles, $10^{\circ}$ in summer and $50^{\circ}$ in winter for PV land plant.

Table 1

Energy generation results

\begin{tabular}{lllll}
\hline $\begin{array}{l}\text { Case } \\
\text { No. }\end{array}$ & \multicolumn{2}{l}{ Building / Area } & $\begin{array}{l}\text { PV Panel } \\
\text { Area }\end{array}$ & $\begin{array}{l}\text { Annual Generation } \\
\text { Energy }\end{array}$ \\
\hline \multirow{2}{*}{ CASE01 } & Building & BL-C Roof & $m^{2}$ & GWh/yr \\
& Roofs & BL-B Roof & 12,794 & 4.25 \\
& & PBBs Roof & 1,174 & 5.69 \\
CASE02 & Parking Area & 38,000 & 0.42 \\
CASE03 & PV Land Plant & 124,313 & 47.04 \\
Total & & 193,552 & 69.98 \\
\hline
\end{tabular}

\subsection{PV System Annual Income}

The annual income is calculated in EGP as per Eq. (1) mentioned in Section 2.9.2. Table 2 shows the annual income results.

Table 2

Annual Income results

\begin{tabular}{lll}
\hline Case No. & Building / Area & Annual Income \\
\hline & & $M E G P / y r$ \\
CASE01 & Building Roof & 11.88 \\
CASE02 & Parking Area & 14.43 \\
CASE03 & PV Land Plant & 53.95 \\
Total & & 80.26 \\
\hline
\end{tabular}

\subsection{PV System Components}

PVsyst energy simulation gives analysis for $P V$ system components. Table 3 illustrates the system components results.

Table 3

The $P V$ system components results

\begin{tabular}{llll}
\hline Case No. & Building / Area & $\begin{array}{l}\text { PV Panels } \\
\text { Qty. }\end{array}$ & $\begin{array}{l}\text { Inverter } \\
\text { Total Power }\end{array}$ \\
\hline & & $E A$ & $k W a c$ \\
CASE01 & Building Roof & 12,213 & 5,200 \\
CASE02 & Parking Area & 14,859 & 6,000 \\
CASE03 & PV Land Plant & 48,633 & 20,200 \\
Total & & 75,705 & 30,400 \\
\hline
\end{tabular}

\subsection{Wind Rose}

The gbXML by Green Building Studio was used for the building model, which was exported from Revit, and then during energy simulation, we can obtain the wind rose of the project.

Figure 7 shows the wind rose of Cairo International Airport. The wind rose range is $7-12 \mathrm{~m} / \mathrm{s}(25.2-$ $43.2 \mathrm{~km} / \mathrm{h}$ ). So, the selected mounting stands wind load is $216 \mathrm{~km} / \mathrm{h}$ that is applicable for the wind load of the project. 


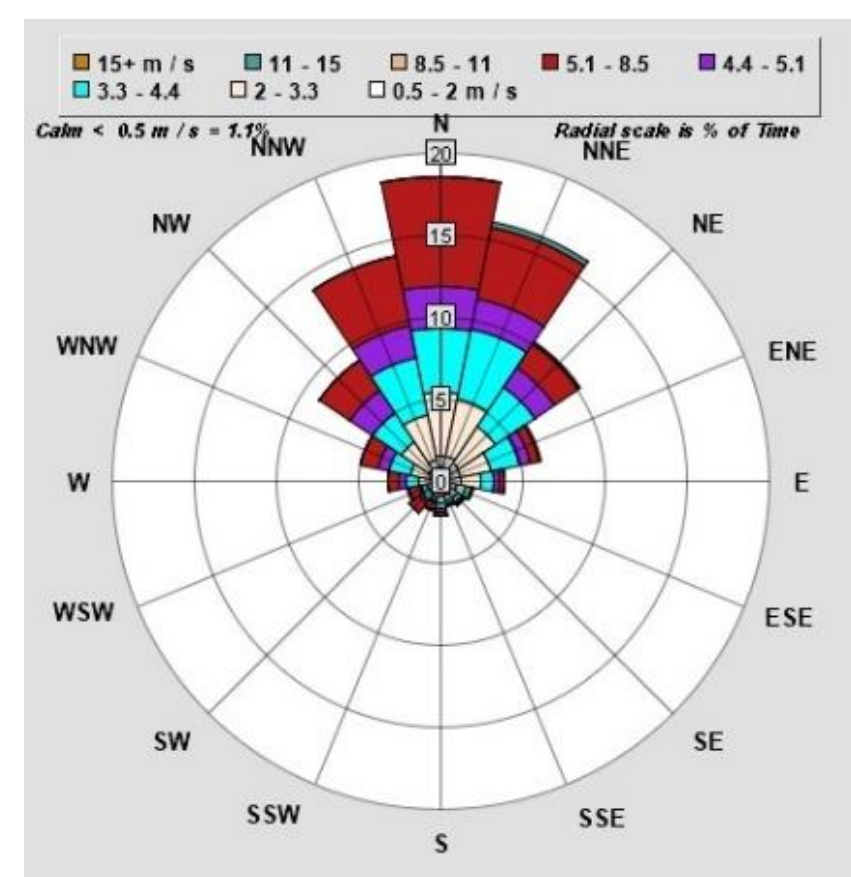

Fig. 7. Wind Rose Results of Cairo International Airport by Revit and Green Building Studio

\subsection{PV System Initial Cost}

Applying the calculation method which was discussed in section 2.9.5, Table 4 illustrates a summary of results of the initial cost for building roofs, parking area, and $P V$ land plant.

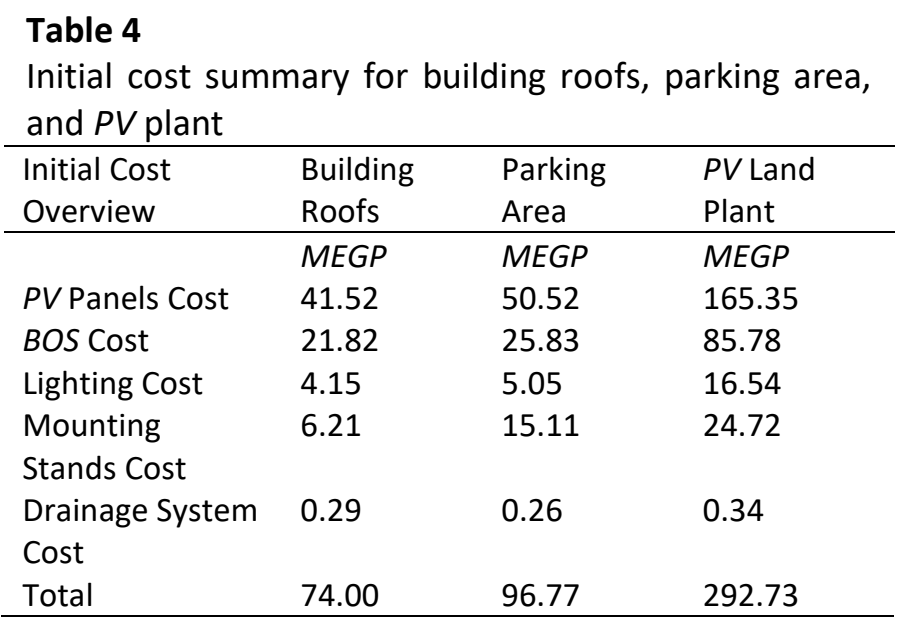

\subsection{PV System Annual Cost}

\subsubsection{Annual cost for building roofs}

Applying the calculation method, which was mentioned in sections 2.9.6-2.9.11, Table 5 to Table 8 show the annual cost calculation by using Manual Cleaning, Water Sprinkler System, Robotic PV Cleaner, and Nanotechnology. 


\section{Table 5}

Annual cost for building roofs using Manual Cleaning

\begin{tabular}{ll}
\hline Using Manual Cleaning & \\
\hline & $E G P$ \\
Maintenance for PV Panels, BOS and Lighting & $1,067,486$ \\
Maintenance for Drainage System & 91,265 \\
Cleaning Manpower & 630,000 \\
Cleaning Special Tools & 4,421 \\
Cleaning Water Usage & 4,001 \\
Total & $1,797,173$ \\
\hline
\end{tabular}

\section{Table 6}

Annual cost for building roofs using Water Sprinkler System

\begin{tabular}{ll}
\hline Using Water Sprinkler System & \\
\hline & $E G P$ \\
Water Piping \& Sprinklers Install. and & 162,972 \\
Maintenance & \\
$P L C$ and Electronic Devices Install. and & 132,045 \\
Maintenance & \\
Maintenance for PV Panels, BOS, Lighting and & $1,067,486$ \\
Electronic Devices & \\
Maintenance for Drainage System & 91,265 \\
Cleaning Manpower & 180,000 \\
Cleaning Special Tools & 1,263 \\
Cleaning Water Usage & 3,334 \\
Total & $1,638,366$ \\
\hline
\end{tabular}

Table 7

Annual cost for building roofs using Robotic PV Cleaner

\begin{tabular}{ll}
\hline Using Robotic $P V$ Cleaner & \\
\hline & $E G P$ \\
Required and Maintenance for Robotic & 94,000 \\
Cleaner \& Brushes & \\
Maintenance for $P V$ Panels, BOS and Lighting & $1,067,486$ \\
Maintenance for Drainage System & 91,265 \\
Cleaning Manpower & 180,000 \\
Cleaning Special Tools & 1,263 \\
Cleaning Water Usage & 2,000 \\
Total & $1,436,015$ \\
\hline
\end{tabular}

\section{Table 8}

Annual cost for building roofs using Nanotechnology

\begin{tabular}{ll}
\hline Using Nanotechnology & \\
\hline & $E G P$ \\
Required Nano Coating Materials and & 378,506 \\
Coating Works & \\
Maintenance for PV Panels, BOS and Lighting & $1,067,486$ \\
Maintenance for Drainage System & 91,265 \\
Cleaning Manpower & 180,000 \\
Cleaning Special Tools & 1,263 \\
Cleaning Water Usage & 2,334 \\
Total & $1,720,854$ \\
\hline
\end{tabular}




\subsubsection{Annual cost for parking area}

Applying the calculation method, which was mentioned in sections 2.9.6-2.9.11, Table 9 to Table 12 show the annual cost calculation by using Manual Cleaning, Water Sprinkler System, Robotic PV Cleaner, and Nanotechnology.

Table 9

Annual cost for parking area using Manual Cleaning

\begin{tabular}{ll}
\hline Using Manual Cleaning & \\
\hline & $E G P$ \\
Maintenance for $P V$ Panels, BOS and Lighting & $1,221,781$ \\
Maintenance for Drainage System & 91,116 \\
Cleaning Manpower & 810,000 \\
Cleaning Special Tools & 5,684 \\
Cleaning Water Usage & 4,868 \\
Total & $2,133,449$ \\
\hline
\end{tabular}

Table 10

Annual cost for parking area using Water Sprinkler System Using Water Sprinkler System Water Piping \& Sprinklers Install. and EGP Maintenance

PLC and Electronic Devices Install. and 186,046

Maintenance 154,743

Maintenance for PV Panels, BOS, Lighting and

Electronic Devices

Maintenance for Drainage System 91,116

Cleaning Manpower

Cleaning Special Tools

1,263

Cleaning Water Usage

4,057

Total $1,839,006$

\section{Table 11}

Annual cost for parking area using Robotic $P V$ Cleaner

\begin{tabular}{ll}
\hline Using Robotic $P V$ Cleaner & \\
\hline & $E G P$ \\
Required and Maintenance for Robotic & 94,000 \\
Cleaner \& Brushes & \\
Maintenance for PV Panels, BOS and Lighting & $1,221,781$ \\
Maintenance for Drainage System & 91,116 \\
Cleaning Manpower & 180,000 \\
Cleaning Special Tools & 1,263 \\
Cleaning Water Usage & 2,434 \\
Total & $1,590,594$ \\
\hline
\end{tabular}




\section{Table 12}

Annual cost for parking area using Nanotechnology

\begin{tabular}{ll}
\hline Using Nanotechnology & \\
\hline & $E G P$ \\
Required Nano Coating Materials and & 460,508 \\
Coating Works & \\
Maintenance for PV Panels, BOS and & $1,221,781$ \\
Lighting & \\
Maintenance for Drainage System & 91,116 \\
Cleaning Manpower & 270,000 \\
Cleaning Special Tools & 1,895 \\
Cleaning Water Usage & 2,840 \\
Total & $2,048,139$ \\
\hline
\end{tabular}

\subsubsection{Annual cost for PV plant}

Applying the calculation method, which was mentioned in sections 2.9.6-2.9.11, Table 13 to Table 16 show the annual cost calculation by using Manual Cleaning, Water Sprinkler System, Robotic PV Cleaner, Truck PV Cleaner, and Nanotechnology.

\section{Table 13}

Annual cost for PV Land Plant using Manual

Cleaning

\begin{tabular}{ll}
\hline Using Manual Cleaning & \\
\hline & $E G P$ \\
Maintenance for PV Panels, BOS and & $4,343,228$ \\
Lighting & \\
Maintenance for Drainage System & 541,488 \\
Cleaning Manpower & $2,610,000$ \\
Cleaning Special Tools & 18,316 \\
Cleaning Water Usage & 15,932 \\
Total & $7,528,965$ \\
\hline
\end{tabular}

\section{Table 14}

Annual cost for $P V$ Land Plant using Water Sprinkler System

\begin{tabular}{ll}
\hline Using Water Sprinkler System & \\
\hline & $E G P$ \\
Water Piping \& Sprinklers Install. and & 546,454 \\
Maintenance & \\
PLC and Electronic Devices Install. and & 494,959 \\
Maintenance & \\
Maintenance for PV Panels, BOS, Lighting and & $4,343,228$ \\
Electronic Devices & \\
Maintenance for Drainage System & 541,488 \\
Cleaning Manpower & 720,000 \\
Cleaning Special Tools & 5,053 \\
Cleaning Water Usage & 13,277 \\
Total & $6,664,459$ \\
\hline
\end{tabular}


Table 15

Annual cost for PV Land Plant using Robotic PV Cleaner, Truck PV Cleaner

\begin{tabular}{lll}
\hline Using Robotic / Truck PV Cleaner & Robotic & Truck \\
\hline & $E G P$ & $E G P$ \\
$\begin{array}{l}\text { Required and Maintenance for } \\
\text { Robotic Cleaner \& Brushes }\end{array}$ & 325,000 & 370,000 \\
$\begin{array}{l}\text { Maintenance for PV Panels, BOS } \\
\text { and Lighting }\end{array}$ & $4,343,228$ & $4,343,228$ \\
Maintenance for Drainage System & 541,488 & 541,488 \\
Cleaning Manpower & 540,000 & 360,000 \\
Cleaning Special Tools & 3,790 & 2,526 \\
Cleaning Water Usage & 7,966 & 26,554 \\
Total & $5,761,472$ & $5,643,796$ \\
\hline
\end{tabular}

Table 16

Annual cost for PV Land Plant using Nanotechnology

\begin{tabular}{ll}
\hline Using Nanotechnology & \\
\hline & EGP \\
Required Nano Coating Materials and Coating & $1,507,235$ \\
Works & \\
Maintenance for PV Panels, BOS and Lighting & $4,343,228$ \\
Maintenance for Drainage System & 541,488 \\
Cleaning Manpower & 990,000 \\
Cleaning Special Tools & 6,948 \\
Cleaning Water Usage & 9,294 \\
Total & $7,398,192$ \\
\hline
\end{tabular}

\subsection{PV System Cost Payback Period}

Using Eq. (3) and Eq. (4) to calculate the cost payback period, Table 17 presents the cost payback time.

Table 17

Cost payback period results

\begin{tabular}{lllll}
\hline Building / Area & Manual Cleaning & $\begin{array}{l}\text { Water Sprinkler } \\
\text { System }\end{array}$ & $\begin{array}{l}\text { Robotic / } \\
\text { Truck Cleaner }\end{array}$ & Nanotechnology \\
\hline & $y r$ & $y r$ & $y r$ & $y r$ \\
Building Roofs & 7.34 & 7.22 & 7.08 & 7.28 \\
Parking Area & 7.87 & 7.69 & 7.54 & 7.82 \\
PV Land Plant & 6.31 & 6.19 & 6.07 & 6.29 \\
\hline
\end{tabular}

\section{Discussions}

Using $P V$ panel $540 \mathrm{~W}$ and dual-seasonal tilt angles, $10^{\circ}$ in summer, and $50^{\circ}$ in winter improves the energy generation.

Results of the initial cost confirmed that PV panels cost is around $50 \%-55 \%$ of the total initial cost as shown in Figure 8. Also, PV panels' quantity is an effective parameter on the initial cost. Increasing the quantity causes an increase in the panels cost as well as in BOS and mounting stands cost. 


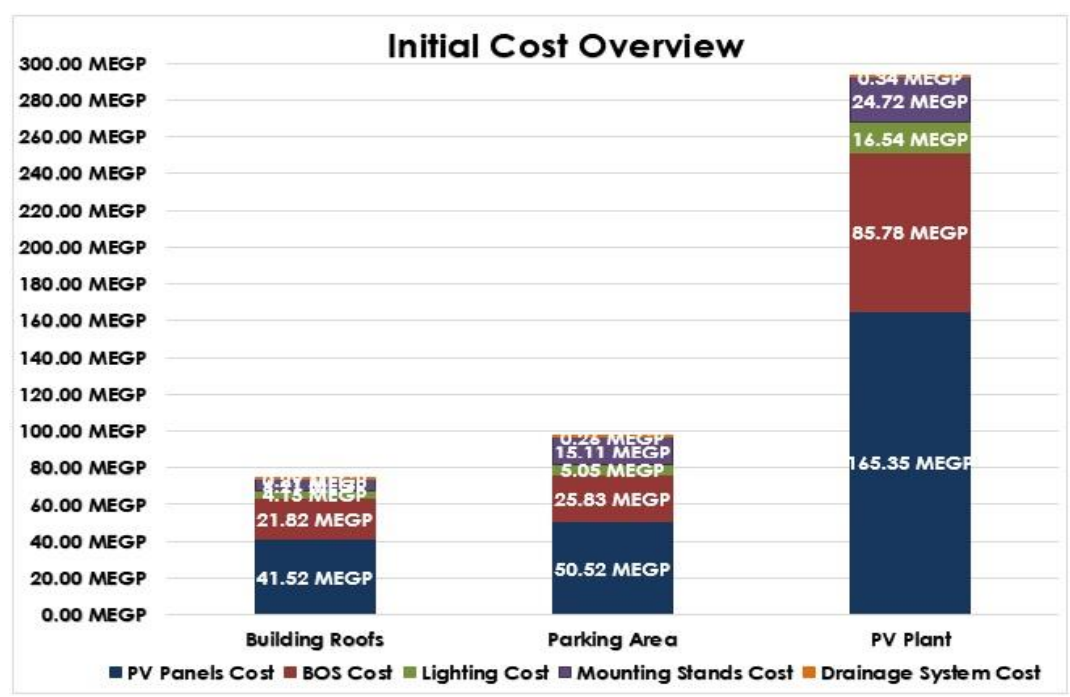

Fig. 8. Results of the initial cost study

Results of the annual cost can be shown in Figure 9 to Figure 11 for building roofs, parking area, and $P V$ plant, respectively. For $P V$ land plant, the results of using Robotic and Truck are very close to each other. The results show that the minimum values are when using Robotic/Truck PV Cleaner and Water Sprinkler System.

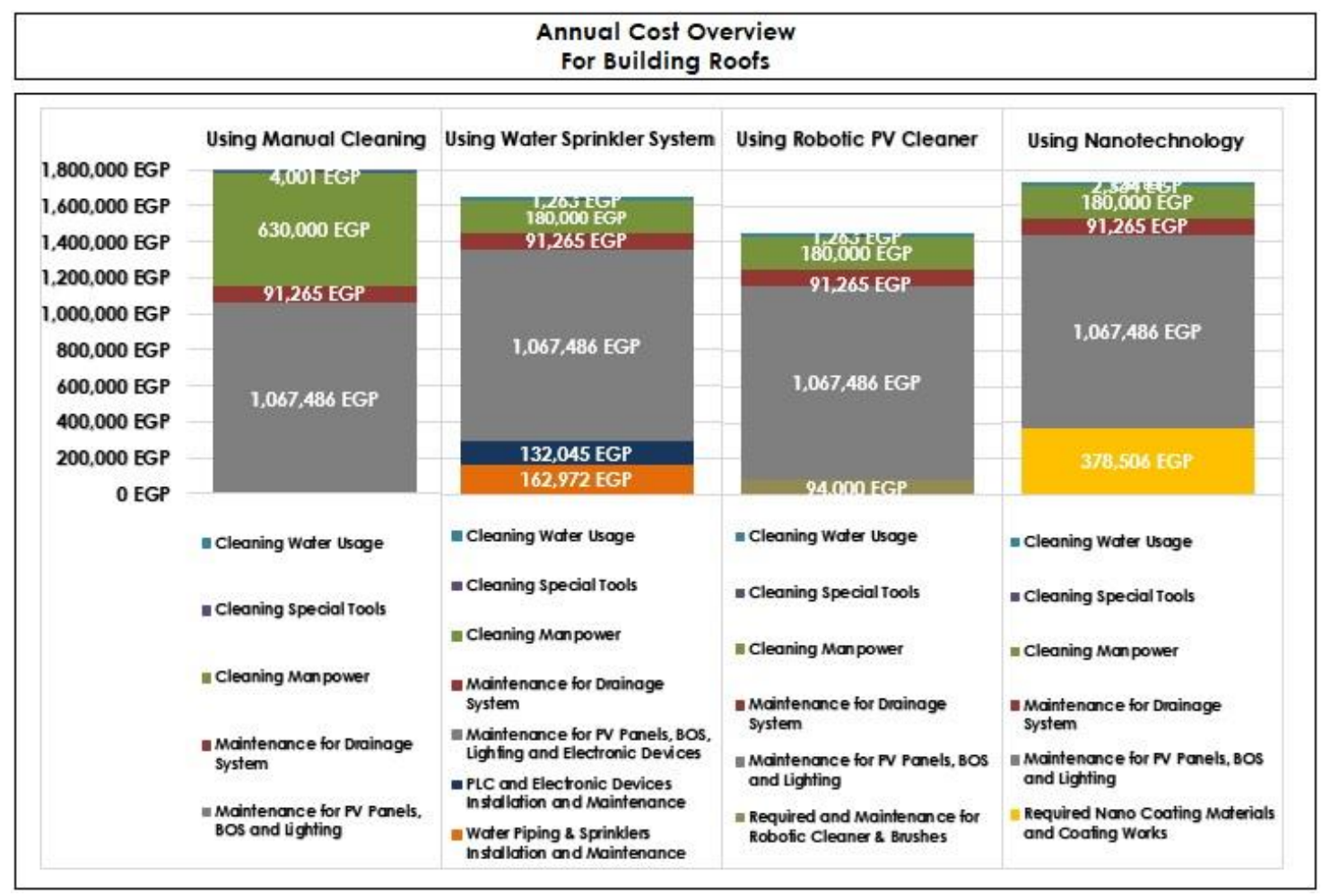

Fig. 9. Results of the annual cost for building roofs 


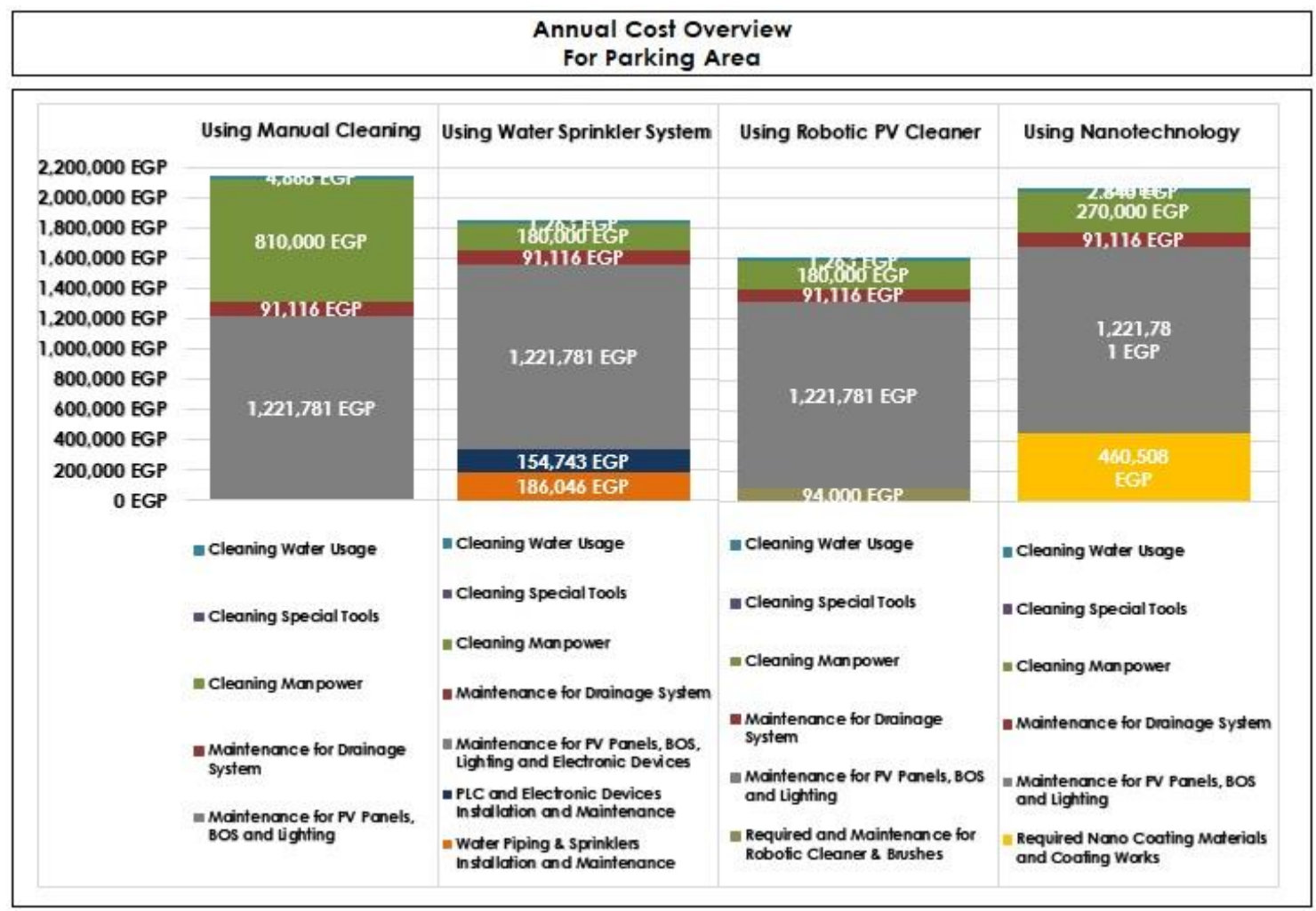

Fig. 10. Results of the annual cost for parking area

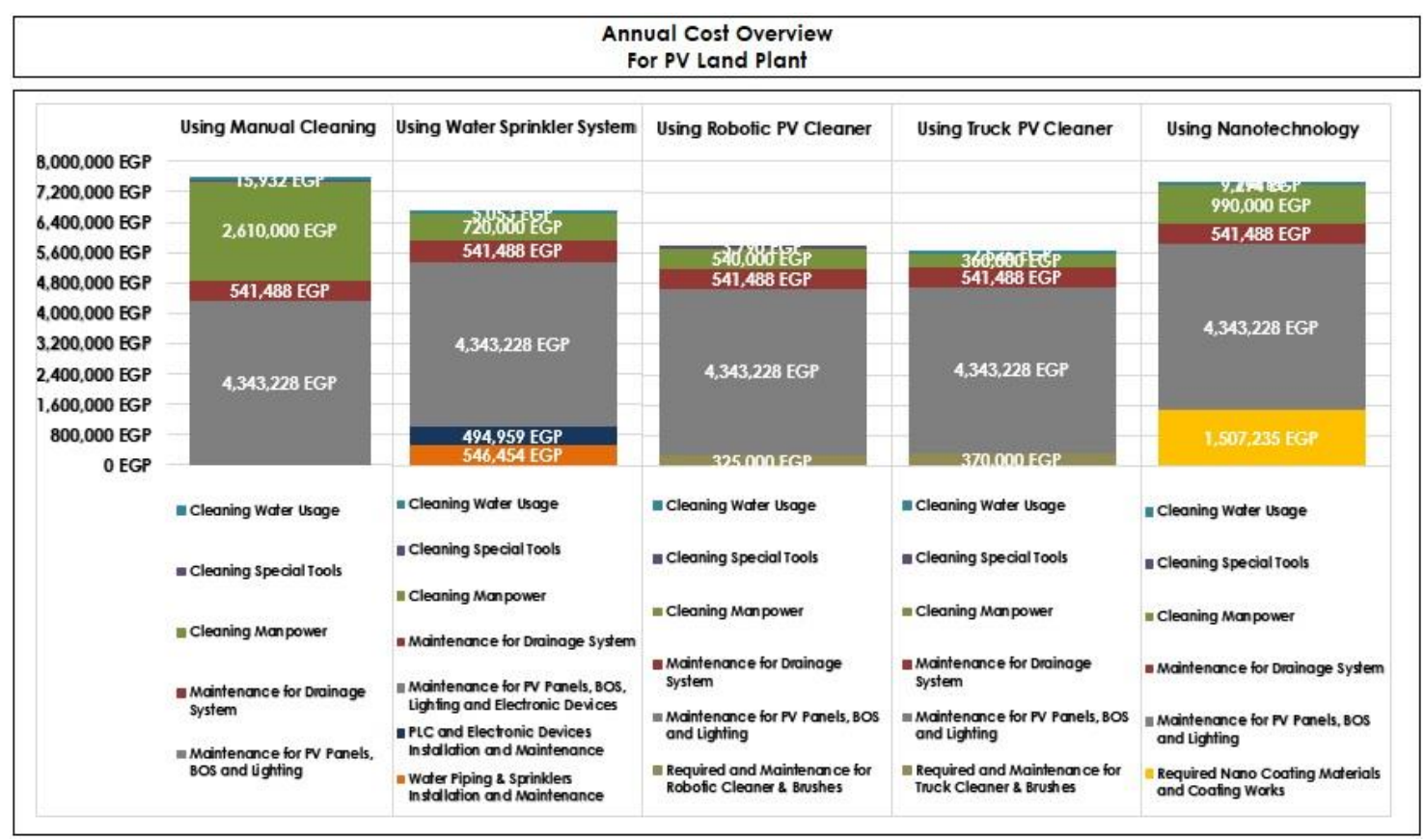

Fig. 11. Results of the annual cost for PV land plant

Quantity of $P V$ panels has a significance effect on the annual cost because of its effect on the maintenance manpower needed for $P V$ panels, BOS, electronic devices, and the required labors for cleaning.

There are various techniques of cleaning. The desired achievement is to protect and keep the $P V$ system giving the optimum performance. So, an accurate technique should be used to get a good performance in dust removal, and easy maintenance procedure. Truck $P V$ cleaner is applicable only 
on the PV plant and its annual cost is very close to that of the Robotic $P V$ cleaner. Selection of the method of cleaning is an important parameter. For instance, the manual cleaning needs a much intensive labor, which maximizes the annual cost. Similarly, the nanotechnology method is expensive due to the expensive cost of coating materials, and the regular coating works needed trough the 25 years. The better methods are water sprinkler system and robotic/truck PV cleaner.

As per shown in Figure 12, the cost payback ranges between 7.54 and 7.87 years for parking area, and here the payback period has increased due to the higher cost of the carport mounting stand. On the other hand, the cost payback period is better when using adjustable stand in building roofs and $P V$ land plant. The cost payback period is ranging between 7.08 and 7.34 years for building roofs and between 6.07 and 6.31 years for $P V$ land plant which is the best period due to having a large area and which provides the ability to use seasonal dual tilt angles without shading losses, so get a higher generation energy and higher annual income. The overall payback time for all $P V$ areas ranges between 6.48 and 6.74 years as per illustrated in Figure 13. Also, the best results are when using water sprinkler system and robotic/truck PV cleaner because the annual costs are the lowest, with no need for more cleaning labor and no need more regular expensive works and materials. In general, the cost payback period results for the three $P V$ areas are in the optimum period, where the results range between 6.07 and 7.87 years and the optimum payback period is between $6-10$ years.

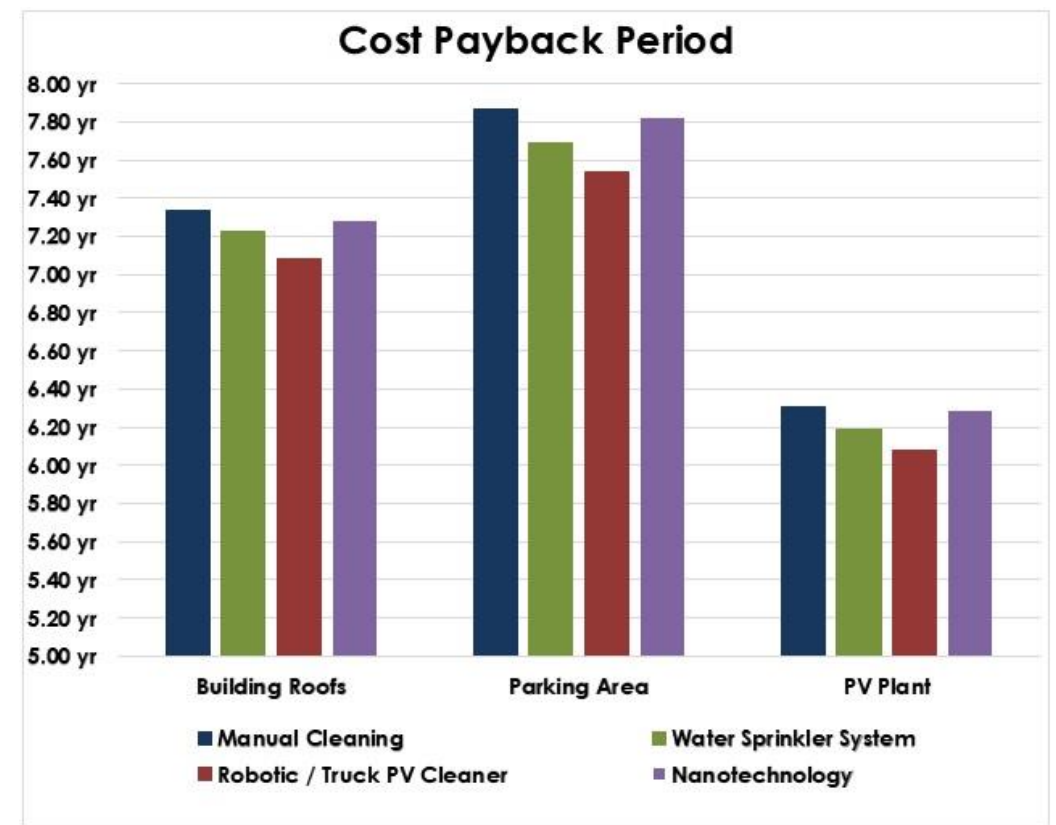

Fig. 12. Results of the cost payback period 


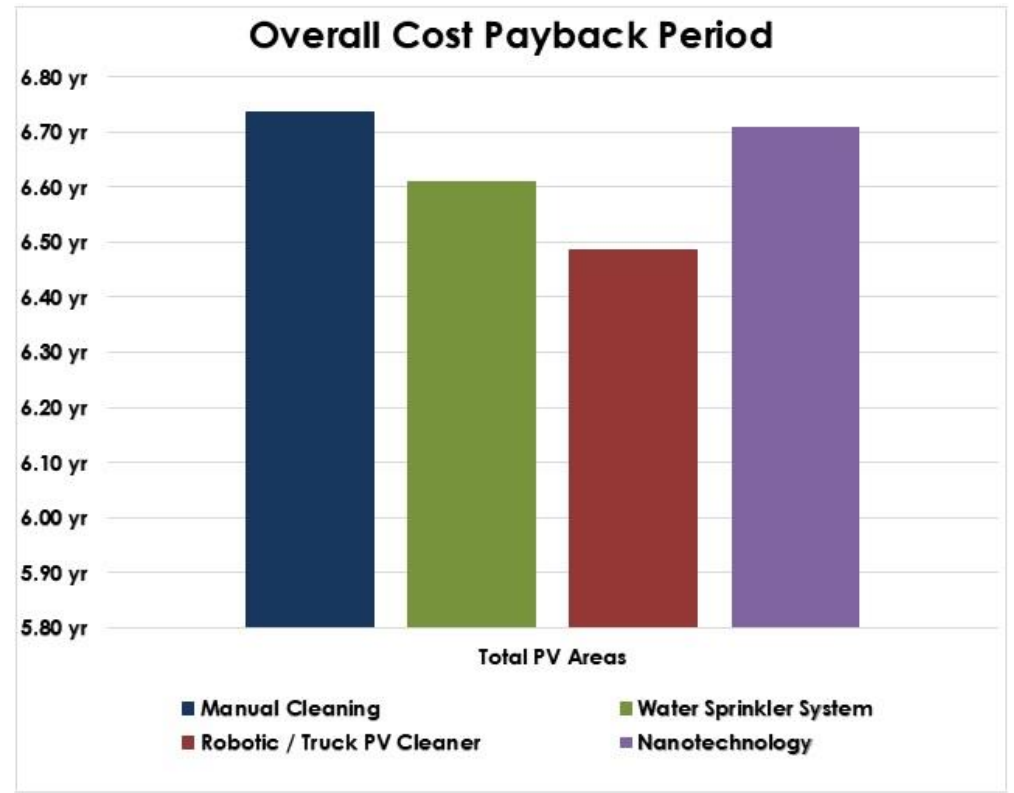

Fig. 13. Results of the overall cost payback period

Table 18 to Table 20 give a brief of the results of the initial cost, annual income, annual cost, and overall payback period for the total $P V$ areas in Cairo International Airport.

Table 18

Summarized results of annual generation energy, initial cost, and annual income for the total $P V$ areas in Cairo International Airport

\begin{tabular}{llll}
\hline & Annual Generation Energy & Initial Cost & Annual Income \\
\hline & $G W h / y r$ & MEGP & MEGP \\
Total PV Areas & 69.98 & 463.49 & 80.26 \\
\hline
\end{tabular}

Table 19

Summarized results of annual cost for the total $P V$ areas in Cairo International Airport

\begin{tabular}{|c|c|c|c|c|}
\hline & \multicolumn{4}{|c|}{ Annual Cost } \\
\hline & $\begin{array}{l}\text { Manual } \\
\text { Cleaning }\end{array}$ & $\begin{array}{l}\text { Water Sprinkler } \\
\text { System }\end{array}$ & $\begin{array}{l}\text { Robotic / } \\
\text { Truck Cleaner }\end{array}$ & Nanotechnology \\
\hline & MEGP & MEGP & MEGP & MEGP \\
\hline $\begin{array}{l}\text { Total } P V \\
\text { Areas }\end{array}$ & 11.46 & 10.14 & 8.79 & 11.17 \\
\hline
\end{tabular}

Table 20

Summarized results of overall payback period for the total $P V$ areas in Cairo International Airport

\begin{tabular}{|c|c|c|c|c|}
\hline & \multicolumn{4}{|c|}{ Overall Cost Payback Period } \\
\hline & $\begin{array}{l}\text { Manual } \\
\text { Cleaning }\end{array}$ & $\begin{array}{l}\text { Water Sprinkler } \\
\text { System }\end{array}$ & $\begin{array}{l}\text { Robotic / } \\
\text { Truck Cleaner }\end{array}$ & Nanotechnology \\
\hline & $y r$ & $y r$ & $y r$ & $y r$ \\
\hline $\begin{array}{l}\text { Total PV } \\
\text { Areas }\end{array}$ & 6.74 & 6.61 & 6.48 & 6.71 \\
\hline
\end{tabular}




\section{Conclusions}

This paper studied various parameters for improving the energy generation for Cairo International Airport Terminal Building 2 (TB2), and Terminal Building 3 (TB3) by using renewable PV energy.

i. The main concluding points can be listed as follows

ii. Using dual-seasonal tilt angles, $10^{\circ}$ in summer and $50^{\circ}$ in winter, improves the energy generation, and accordingly gives higher annual income and a better cost payback period.

iii. The availability of large area provides good space between rows of $P V$ modules and the ability to use seasonal dual tilt angles without shading losses, which provide a higher generation and higher annual income, thus providing better cost payback period.

iv. PVsyst is a multifunctional energy analysis and optimization tool, which gives optimum orientation, $P V$ system components, and $P V$ system production energy.

v. Quantity of $P V$ panels is a major parameter of the overall cost as it affects the initial and annual costs, and payback period.

vi. The cost of carport stand in the parking areas is more expensive as it increases initial cost and the cost payback period.

vii. Using the method of manual cleaning causes an increase of the annual cost, which makes it precede nanotechnology method.

viii. The annual cost of using water sprinkler system, and robotic/truck $P V$ cleaner are the lowest and good selections for $P V$ panel system.

ix. Robotic/Truck $P V$ cleaner is recommended for cleaning.

x. $P V$ panels cost is around $50 \%-55 \%$ of the total initial cost.

xi. The annual cost for a 25 -year lifetime $P V$ system represents $2 \%-2.5 \%$ of the initial cost.

xii. The study aims to improve the produced energy to be around $70 \mathrm{GWh} / \mathrm{yr}$, which could save about $60 \%$ of the annual energy consumption of Cairo International Airport, Terminal Building 2 (TB2) and Terminal Building 3 (TB3).

xiii. The study demonstrates the initial cost to be 463 MEGP, the annual income is 80.26 MEGP, and the annual cost around 11.5 MEGP.

xiv. The study gives a good payback period which is $61 / 2$ years.

\section{References}

[1] Sukumaran, Sreenath, and K. Sudhakar. "Fully solar powered airport: A case study of Cochin International airport." Journal of Air Transport Management 62 (2017): 176-188. https://doi.org/10.1016/j.jairtraman.2017.04.004

[2] International Civil Aviation Organization (ICAO). Renewable Energy for Aviation: Practical Applications to Achieve Carbon Reductions and Cost Savings. Transforming Global Aviation Collection, 2017.

[3] Dey, Diptiman, and Bidyadhar Subudhi. "Design, simulation and economic evaluation of $90 \mathrm{~kW}$ grid connected Photovoltaic system." Energy Reports 6 (2020): 1778-1787. https://doi.org/10.1016/i.egyr.2020.04.027

[4] Thomas, Austin, and Pavan Racherla. "Constructing statutory energy goal compliant wind and solar PV infrastructure pathways." Renewable Energy 161 (2020): 1-19. https://doi.org/10.1016/j.renene.2020.06.141

[5] Abdullah, Amira Lateef, Suhaimi Misha, Noreffendy Tamaldin, Mohd Afzanizam Mohd Rosli, and Fadhil Abdulameer Sachit. "Numerical analysis of solar hybrid photovoltaic thermal air collector simulation by ANSYS." CFD Letters 11, no. 2 (2019): 1-11.

[6] Hegazy, Aiat. "Estimation of Optimum Tilt Angles for Solar Collector and Gained Energy at Cairo, Egypt." International Journal of Innovative Science, Engineering \& Technology 6 (2019): 249-258.

[7] Abdullah, Amira Lateef, Suhaimi Misha, Noreffendy Tamaldin, Mohd Afzanizam Mohd Rosli, and Fadhil Abdulameer Sachit. "Hybrid Photovoltaic Thermal PVT Solar Systems Simulation via Simulink/Matlab." CFD Letters 11, no. 4 (2019): 64-78. 
[8] Bakri, Mohd Azwan Mohd, J. Salmah, S. Abd Rahim, and K. Norman. "A study on Agro-Hybrid Farm Vehicle with Small Onboard Solar Photovoltaic for Herbicide Spraying in Oil Palm Plantation." Journal of Advanced Research in Applied Sciences and Engineering Technology 17, no. 1 (2019): 61-77.

[9] Sachit, Fadhil Abdulameer, Mohd Afzanizam Mohd Rosli, Noreffendy Tamaldin, Suhaimi Misha, and Amira Lateef Abdullah. "Modelling, validation and analyzing performance of serpentine-direct PV/T solar collector design." CFD Letters 11, no. 2 (2019): 50-65.

[10] He, Gaofa, Chuande Zhou, and Zelun Li. "Review of self-cleaning method for solar cell array." Procedia Engineering 16 (2011): 640-645. https://doi.org/10.1016/i.proeng.2011.08.1135

[11] Sreenath, S., K. Sudhakar, A. F. Yusop, Erdem Cuce, and Evgeny Solomin. "Analysis of solar PV glare in airport environment: Potential solutions." Results in Engineering $5 \quad$ (2020): 100079. https://doi.org/10.1016/j.rineng.2019.100079

[12] Sacks, Rafael, Chuck Eastman, Ghang Lee, and Paul Teicholz. BIM handbook: A guide to building information modeling for owners, designers, engineers, contractors, and facility managers. John Wiley \& Sons, 2018. https://doi.org/10.1002/9781119287568

[13] Salameh, Tareq, Mamdouh El Haj Assad, Muhammad Tawalbeh, Chaouki Ghenai, Adel Merabet, and Hakan F. Öztop. "Analysis of cooling load on commercial building in UAE climate using building integrated photovoltaic façade system." Solar Energy 199 (2020): 617-629. https://doi.org/10.1016/i.solener.2020.02.062

[14] Emeara, Mohamed S., Ahmed Farouk Abdelgawad, and Ahmed H. El Abagy. "A Case Study of Cairo International Airport "CIA": Proposed Installation of Photovolatic PV" for High Energy-Production." International Journal of Mechanical and Production Engineering Research and Development (IJMPERD) 10, no. 5 (2020): 399-410. https://doi.org/10.24247/ijmperdoct202040

[15] Kavitha, B., and M. V. Molykutty. "Life cycle energy analysis of a glazed commercial building using building information modelling (BIM) tools." Materials Today: Proceedings $37 \quad$ (2021): 940-946. https://doi.org/10.1016/i.matpr.2020.06.148

[16] Abanda, F. H., and L. Byers. "An investigation of the impact of building orientation on energy consumption in a domestic building using emerging BIM (Building Information Modelling)." Energy 97 (2016): 517-527. https://doi.org/10.1016/i.energy.2015.12.135

[17] Hernández-Moro, J., and Jose Manuel Martinez-Duart. "Analytical model for solar PV and CSP electricity costs: Present LCOE values and their future evolution." Renewable and Sustainable Energy Reviews 20 (2013): 119-132. https://doi.org/10.1016/i.rser.2012.11.082

[18] Kiatreungwattana, Kosol, Gail Mosey, Shea Jones-Johnson, Craig Dufficy, Joe Bourg, Angela Conroy, Meghan Keenan, William Michaud, and Katie Brown. Best Practices for Siting Solar Photovoltaics on Municipal Solid Waste Landfills. A Study Prepared in Partnership with the Environmental Protection Agency for the RE-Powering America's Land Initiative: Siting Renewable Energy on Potentially Contaminated Land and Mine Sites. No. NREL/TP-7A3052615. National Renewable Energy Lab.(NREL), Golden, CO (United States), 2013. https://doi.org/10.2172/1076646

[19] Eicker, Ursula. Solar technologies for buildings. John Wiley \& Sons, 2006.

[20] SolarFirst. "Roof Mounting." Xiamen Solar First Energy Technology Co., Ltd. Accessed December 4, 2020. https://www.pvsolarfirst.com/roof-mounting_c1

[21] Saravanan, V. S., and S. K. Darvekar. "Solar Photovoltaic panels cleaning methods: A Review." International Journal of Pure and Applied Mathematics 118 (2018): 1-17.

[22] Deb, Dipankar, and Nisarg L. Brahmbhatt. "Review of yield increase of solar panels through soiling prevention, and a proposed water-free automated cleaning solution." Renewable and Sustainable Energy Reviews 82 (2018): 33063313. https://doi.org/10.1016/i.rser.2017.10.014

[23] Alibaba Group. "Alibaba Products." Alibaba. Accessed December 4, 2020. https://www.alibaba.com/.

[24] Smart Wantong. "PV Intelligent Cleaning Robots." Fully Intelligent Photovoltaic Cleaning Robot. Accessed January 4, 2021. https://www.smartwantong.com/en/solution.html.

[25] Alghamdi, Abdulsalam S., AbuBakr S. Bahaj, Luke S. Blunden, and Yue Wu. "Dust removal from solar PV modules by automated cleaning systems." Energies 12, no. 15 (2019): 2923. https://doi.org/10.3390/en12152923

[26] Tu, Qiang, Jianlei Mo, Regina Betz, Lianbiao Cui, Ying Fan, and Yu Liu. "Achieving grid parity of solar PV power in China-The role of Tradable Green Certificate." Energy Policy 144 (2020): 111681. https://doi.org/10.1016/j.enpol.2020.111681

[27] Ali, Md Yeamin, Mehadi Hassan, Md Atiqur Rahman, Abdulla-Al Kafy, Iffat Ara, Akib Javed, and Md Redwanur Rahman. "Life cycle energy and cost analysis of small scale biogas plant and solar PV system in rural areas of Bangladesh." Energy Procedia 160 (2019): 277-284. https://doi.org/10.1016/j.egypro.2019.02.147

[28] Egyptian News and Renewable Energy Authority. "Renewable Energy Legislation." News and Renewable Energy Authority. Accessed December 4, 2020. http://www.nrea.gov.eg/Investors/Legislation. 
[29] ENF. "ENF Solar - Solar Companies and Products." ENF Solar, Ltd. Accessed December 4, 2020. https://www.enfsolar.com/

[30] Solar Market Egypt. "Solar Products." Solar Market. Accessed December 4, 2020. https://www.solarmarketegypt.com/ar.

[31] Global Techniques for Energy. "Save On Solar." Solar Panel Manufacturer. Accessed December 4, 2020. https://www.globaltechniques.solar/.

[32] Misr El Hegaz. "Pipes \& Fittings Products." Plastics Manufacturer. Accessed December 4, 2020. https://misrelhegaz.com/.

[33] Ubuy. "Ubuy Products." Products \& Categories. Accessed December 4, 2020. https://www.ubuy.com.eg/en/.

[34] Youm7. "Water Cost." Youm7. Accessed December 4, 2020. https://www.youm7.com/.

[35] CM-PPR. "Polypropylene Pipes \& Fittings Products." Plastics Manufacturer. Accessed December 4, 2020. http://cmppr.com/.

[36] Percenta Nanotechnology. "Nano Coating for Solar Panels." Percenta-Nanoproducts. Accessed December 4, 2020. https://percenta-nanoproducts.com/nano-coating-for-solar-panels.html 